\title{
Article \\ Critical Role of Al Pair Sites in Methane Oxidation to Methanol on Cu-Exchanged Mordenite Zeolites
}

\author{
Peijie Han ${ }^{1}$, Zhaoxia Zhang ${ }^{1}$, Zheng Chen ${ }^{1}$, Jingdong Lin ${ }^{1} \mathbb{D}$, Shaolong Wan ${ }^{1}$, Yong Wang ${ }^{2} \mathbb{D}$ \\ and Shuai Wang 1,*(D)
}

1 State Key Laboratory for Physical Chemistry of Solid Surfaces, Collaborative Innovation Center of Chemistry for Energy Materials, National Engineering Laboratory for Green Chemical Productions of Alcohols-Ethers-Esters, and College of Chemistry and Chemical Engineering, Xiamen University, Xiamen 361005, China; happyj@stu.xmu.edu.cn (P.H.); zzxyyy@xmu.edu.cn (Z.Z.); chenzheng@stu.xmu.edu.cn (Z.C.); jdlin@xmu.edu.cn (J.L.); swan@xmu.edu.cn (S.W.)

2 Voiland School of Chemical Engineering and Bioengineering, Washington State University, Pullman, WA 99164, USA; wang42@wsu.edu

* Correspondence: shuaiwang@xmu.edu.cn

Citation: Han, P.; Zhang, Z.; Chen, Z.; Lin, J.; Wan, S.; Wang, Y.; Wang, S. Critical Role of Al Pair Sites in Methane Oxidation to Methanol on $\mathrm{Cu}$-Exchanged Mordenite Zeolites. Catalysts 2021, 11, 751. https:// doi.org/10.3390/catal11060751

Academic Editor:

Wladimir Reschetilowski

Received: 31 May 2021

Accepted: 17 June 2021

Published: 19 June 2021

Publisher's Note: MDPI stays neutral with regard to jurisdictional claims in published maps and institutional affiliations.

Copyright: (C) 2021 by the authors Licensee MDPI, Basel, Switzerland. This article is an open access article distributed under the terms and conditions of the Creative Commons Attribution (CC BY) license (https:/ / creativecommons.org/licenses/by/ $4.0 /)$.

\begin{abstract}
Cu}$-exchanged aluminosilicate zeolites have been intensively studied for the selective oxidation of methane to methanol via a chemical looping manner, while the nature of active Cu-oxo species for these catalysts is still under debate. This study inquired into the effects of $\mathrm{Al}$ distribution on methane oxidation over $\mathrm{Cu}$-exchanged aluminosilicate zeolites, which provided an effective way to discern the activity difference between mononuclear and polynuclear $\mathrm{Cu}$-oxo species. Specifically, conventional $\mathrm{Na}^{+} / \mathrm{Co}^{2+}$ ion-exchange methods were applied to quantify isolated $\mathrm{Al}$ and $\mathrm{Al}$ pair (i.e., $\left.\mathrm{Al}-\mathrm{OH}-(\mathrm{Si}-\mathrm{O})_{1-3}-\mathrm{Al}-\mathrm{OH}\right)$ sites for three mordenite (MOR) zeolites, and a correlation was established between the reactivity of the resultant $\mathrm{Cu}$-MOR catalysts and the portions of the accessible framework $\mathrm{Al}$ sites. These results indicated that the $\mathrm{Cu}$-oxo clusters derived from the $\mathrm{Al}$ pair sites were more reactive than the $\mathrm{CuOH}$ species grafted at the isolated $\mathrm{Al}$ sites, which is consistent with in situ ultraviolet-visible spectroscopic characterization and density functional theory calculations. Further theoretical analysis of the first $\mathrm{C}-\mathrm{H}$ bond cleavage in methane on these $\mathrm{Cu}$-oxo species unveiled that stabilization of the formed methyl group was the predominant factor in determining the reactivity of methane oxidation.
\end{abstract}

Keywords: methane oxidation; methanol; mordenite zeolite; Cu-oxo species; Al pair site; $\mathrm{C}-\mathrm{H}$ activation

\section{Introduction}

Methane is a major ingredient of many earth-abundant carbon resources (e.g., natural gas, combustible ice, and shale gas) [1-3]. On one hand, due to its chemical inertness brought forth by the highly stable and very weakly polarized $\mathrm{C}-\mathrm{H}$ bonds (with the first $\mathrm{C}-\mathrm{H}$ bond dissociation enthalpy up to $\approx 435 \mathrm{~kJ} \mathrm{~mol}^{-1}$ ), methane is mainly used as a simple gaseous fuel to provide thermal power at present. On the other hand, it is of great interest to realize an efficient conversion of methane to valuable liquid fuels or chemicals, considering that methane itself is difficult to store and transport compared to conventional liquid fuels. In recent years, the selective oxidation of methane to $\mathrm{C}_{1}$ platform molecules (such as $\mathrm{CH}_{3} \mathrm{OH}$ and $\mathrm{HCHO}$ ) has attracted much attention [4-7]. Since $\mathrm{CH}_{3} \mathrm{OH}$ and $\mathrm{HCHO}$ are more reactive than the methane reactant and tend to be further oxidized to thermodynamically more stable products (i.e., $\mathrm{CO}$ and $\mathrm{CO}_{2}$ ), the major challenge is to achieve a high selectivity of $\mathrm{CH}_{3} \mathrm{OH} / \mathrm{HCHO}$ at practical methane conversions. Consequently, the primary focus in this research area has been aiming at exploring novel catalysts that can enable methane oxidation under milder conditions and thus suppress the undesired over-oxidation reactions. 
In recent years, a new catalytic approach for the partial oxidation of methane to methanol on copper-exchanged aluminosilicate zeolites (Cu-zeolite for short) has been intensively explored [7-12], which was inspired by methane monooxygenase (MMO) [13]. $\mathrm{MMO}$ is a biological enzyme present in microorganisms that can directly catalyze methane oxidation to methanol at ambient temperature and pressure with the $\mathrm{Cu}$ or Fe-oxo clusters acting as the active center. Methane oxidation on $\mathrm{Cu}$-zeolites is generally carried out in a stepwise manner (so-called "chemical looping"), in which the $\mathrm{Cu}$-based catalysts are first activated in an oxidative environment at high temperature $(>673 \mathrm{~K})$ and then used to oxidize methane to form bound methoxy species at much lower temperature $(<523 \mathrm{~K})$, which is followed by the hydrolysis of these methoxy species to methanol to complete the cycle. With this "chemical looping" strategy, Cu-oxo species constructed within the micropores of aluminosilicate zeolites (such as Cu-MOR [14-21], Cu-MFI [15,22,23], and $\mathrm{Cu}-\mathrm{CHA}$ [24]) are shown to exhibit high methanol selectivities in the direct oxidation of methane ( $>80 \%$ ) with the methanol yields of up to $200 \mathrm{\mu mol} \mathrm{g}_{\mathrm{cat}}{ }^{-1}$ per cycle [12].

Although great efforts have been made in developing new $\mathrm{Cu}$-zeolites for selective methane oxidation, the nature of active sites involved in these Cu-based catalysts is still under debate. For instance, at least five types of $\mathrm{Cu}$-oxo species (e.g., $[\mathrm{CuOH}]^{+}[21,25,26]$, $\left[\mathrm{Cu}_{2} \mathrm{O}\right]^{2+}[21,27],\left[\mathrm{Cu}_{2} \mathrm{O}_{2}\right]^{2+}[15],\left[\mathrm{Cu}_{3} \mathrm{O}_{3}\right]^{2+}[17,27]$, and $\left.\left[\mathrm{Cu}_{5} \mathrm{O}_{5}\right]^{2+}[28]\right)$ have been proposed as the active sites of the $\mathrm{Cu}-\mathrm{MOR}$ catalysts. The uncertainty is in part due to the fact that the formation of $\mathrm{Cu}$-containing species grafted at the framework $\mathrm{Al}$ sites is sensitive to the $\mathrm{Al}$ distribution of the parent zeolite host, which varies among zeolite samples synthesized via different methods or conditions [29-33]. In general, the $\mathrm{CuOH}$ species prefer to bind to isolated $\mathrm{Al}$ sites in the zeolite framework, while the presence of multinuclear $\mathrm{Cu}$-oxo species requires the presence of vicinal framework $\mathrm{Al}$ sites (known as $\mathrm{Al}$ pair sites). However, not much attention has been paid to the correlation between the Al distribution of the zeolite host and the reactivity of the resultant $\mathrm{Cu}$-containing species [12], which is critical to discern the active sites for methane activation.

This study attempted to unveil the requirement of $\mathrm{Al}$ distribution for the reactivity of $\mathrm{Cu}$-zeolite catalysts in methane oxidation to methanol and gain an insight into the origin of activity difference among the $\mathrm{Cu}$-oxo species formed. To achieve these goals, this study focused on the Cu-MOR catalysts, which are among the most active ones for methane oxidation reported in the literature [12]. Three commercial H-MOR zeolite samples were selected here as the hosts of $\mathrm{Cu}$-oxo species, because they possessed distinct $\mathrm{Al}$ distributions for the accessible framework $\mathrm{Al}$ sites as quantified by the $\mathrm{Na}^{+} / \mathrm{Co}^{2+}$ ionexchange methods. The effects of $\mathrm{Cu}$ loading on the activity of $\mathrm{Cu}-\mathrm{MOR}$ catalysts in methane oxidation to methanol revealed that the $\mathrm{Cu}$-containing species formed at low $\mathrm{Cu}$ loadings were the predominant active sites for methane activation, which plausibly resided within the eight-member-ring channels of the MOR structure. Combined in situ ultraviolet-visible spectroscopy and density functional theory treatments indicated that both $\mathrm{CuOH}$ species grafted at the isolated $\mathrm{Al}$ sites and $\mathrm{Cu}$-oxo clusters grafted at the $\mathrm{Al}$ pair sites (e.g., $\mathrm{Cu}_{2} \mathrm{O}_{2}$ or $\mathrm{Cu}_{3} \mathrm{O}_{3}$ ) were formed at the low $\mathrm{Cu}$ loadings, while the latter was more reactive, as they can more efficiently stabilize the methyl intermediate via bridged-O $(\mu-\mathrm{O})$ centers. These findings shed light on the importance of $\mathrm{Al}$ distribution in determining the reactivity of $\mathrm{Cu}$-zeolite catalysts, contributing to a fundamental guidance of the rational design of $\mathrm{Cu}$-zeolite catalysts for the methane-to-methanol process.

\section{Results and Discussion}

\subsection{Preparation and Characterization of $\mathrm{Cu}-\mathrm{MOR}$ Catalysts}

In order to investigate the effects of $\mathrm{Al}$ distribution on the activity of $\mathrm{Cu}$-exchanged mordenite zeolites (denoted as $\mathrm{Cu}-\mathrm{MOR}$ ) for methane partial oxidation to methanol, three commercial $\mathrm{H}-\mathrm{MOR}$ samples with different $\mathrm{Si} / \mathrm{Al}$ molar ratios (14-40; provided by the suppliers) were selected as the parent zeolite hosts, which are named henceforth as MOR-A $(\mathrm{Si} / \mathrm{Al}=14), \mathrm{MOR}-\mathrm{B}(\mathrm{Si} / \mathrm{Al}=20)$, and MOR-C $(\mathrm{Si} / \mathrm{Al}=40)$, respectively. Since the charge induced by the isomorphous substitution of $\mathrm{Al}$ atoms into the $\mathrm{SiO}_{4}$ tetrahedra units of 
the zeolite framework is balanced by exchangeable proton sites, $\mathrm{Na}^{+} / \mathrm{Co}^{2+}$ ion-exchange methods were applied here to assess the components of $\mathrm{Al}$ sites in these H-MOR samples that are available for grafting the $\mathrm{Cu}$-containing species. As illustrated in Scheme $1, \mathrm{Na}^{+}$ cations can replace the protons associated with the accessible framework $\mathrm{Al}$ sites (denoted as $\mathrm{Al}_{\text {acce }}$ ) with a stoichiometric ratio of $1: 1$, while $\mathrm{Co}^{2+}$ cations can selectively replace the protons derived from paired $\mathrm{Al}$ sites (denoted as $\mathrm{Al}_{\text {pair }}$ ) within the $\mathrm{Al}_{\text {acce }}$ sites [17,29-33], which are defined for two neighboring framework $\mathrm{Al}$ sites separated by less than three $\mathrm{Si}$ atoms in the ring structures of $\mathrm{MOR}$ (i.e., $\left.\mathrm{Al}-\mathrm{OH}-(\mathrm{Si}-\mathrm{O})_{1-3}-\mathrm{Al}-\mathrm{OH}\right)$. It needs to be noted that the two protons derived from one pair of $\mathrm{Al}$ sites could also be replaced by two $\mathrm{Co}^{2+}$ cations (corresponding to a stoichiometric $\mathrm{Co} / \mathrm{Al}$ ratio of $1 / 1$ ), but its occurrence requires a higher ion-exchange temperature (e.g., $350 \mathrm{~K}$ ) [34]. In other words, the $\mathrm{Co}^{2+}$ exchange process carried out at ambient temperature (c.a. $298 \mathrm{~K}$ ) in our study enables a selective replacement of the two protons of one pair of $\mathrm{Al}$ sites by one $\mathrm{Co}^{2+}$ cation (corresponding to a stoichiometric $\mathrm{Co} / \mathrm{Al}$ ratio of 1/2). Consequently, the amount for the available isolated $\mathrm{Al}$ sites within the zeolite framework (denoted as $\mathrm{Al}_{\text {isol }}$ ) was obtained from the difference between those for the $\mathrm{Al}_{\text {acce }}$ and $\mathrm{Al}_{\text {pair }}$ sites,

$$
n\left(\mathrm{Al}_{\text {isol }}\right)=n\left(\mathrm{Al}_{\text {acce }}\right)-n\left(\mathrm{Al}_{\text {pair }}\right) \text {. }
$$

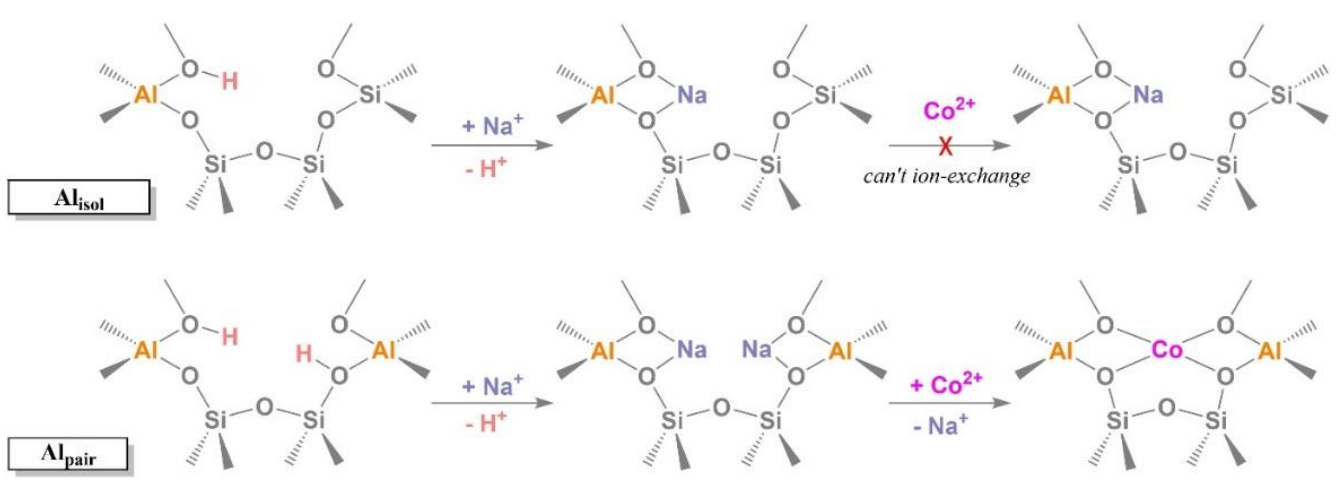

Scheme 1. Selective ion-exchanges of $\mathrm{Na}^{+}$and $\mathrm{Co}^{2+}$ ions with protons residing at isolated $\mathrm{Al}\left(\mathrm{Al}_{\text {isol }}\right)$ and $\mathrm{Al}$ pair $\left(\mathrm{Al}_{\text {pair }}\right)$ sites of the zeolite framework.

Table 1 shows that the measured portions of $\mathrm{Al}_{\text {acce }}$ for the MOR-A, MOR-B, and MOR-C samples (with respect to the total $\mathrm{Al}$ content) are $57 \%, 31 \%$, and $65 \%$, respectively, which reflects the presence of extra-framework $\mathrm{Al}$ sites and the inaccessibility of a portion of the framework $\mathrm{Al}$ sites to the ion exchange because of steric hindrance. The $\mathrm{Al}_{\text {pair }} / \mathrm{Al}_{\text {isol }}$ ratios for these MOR samples follow an order of MOR-B (0.8) < MOR-C (2.4) < MOR-A (7.1), depending not only on the $\mathrm{Si} / \mathrm{Al}$ ratio of the zeolites but also their supplier (MOR-A and MOR-C from Clariant, MOR-B from Nankai University Catalyst Co., Ltd.). Previous studies have found that the $\mathrm{Al}$ distribution of the aluminosilicate zeolites is very sensitive to the method and condition used in their synthesis [29-33], which may account for this observed trend of the $\mathrm{Al}_{\text {pair }} / \mathrm{Al}_{\text {isol }}$ ratio. As shown below, the diverse $\mathrm{Al}$ distributions of these MOR samples enable us to examine the influence of the different $\mathrm{Al}$ sites on the catalytic activity of $\mathrm{Cu}$-exchanged aluminosilicate zeolites in methane oxidation.

Table 1. Si/Al ratios of parent $\mathrm{H}-\mathrm{MOR}$ hosts and corresponding portions of framework $\mathrm{Al}$ sites accessible to $\mathrm{Na}^{+} / \mathrm{Co}^{2+}$ ion-exchanges ${ }^{\text {a }}$.

\begin{tabular}{|c|c|c|c|c|c|}
\hline Sample & Si/Al & $A l_{\text {acce }}(\%)^{b}$ & $A 1_{\text {pair }}(\%)^{b}$ & $A l_{\text {isol }}(\%)^{b}$ & $\mathrm{Al}_{\text {pair }} / \mathbf{A l}_{\text {iso }}$ \\
\hline MOR-A & 14 & 57 & 50 & 7 & 7.1 \\
\hline MOR-B & 20 & 31 & 14 & 17 & 0.82 \\
\hline MOR-C & 40 & 65 & 46 & 19 & 2.4 \\
\hline
\end{tabular}


$\mathrm{Cu}-\mathrm{MOR}$ catalysts were prepared via a conventional aqueous ion-exchange method at a constant $\mathrm{pH}$ value of around $5.4[16,17]$, during which $\mathrm{Cu}^{2+}$ ions can exchange with the protons associated with the accessible framework $\mathrm{Al}$ atoms. X-ray diffraction (XRD) patterns of these catalysts before or after methane oxidation were nearly identical to that of the parent MOR host (MOR-A used as an example in Figure 1a), indicating the framework of the MOR samples remained stable during the catalyst preparation and methane oxidation processes. The absence of diffraction peaks of $\mathrm{Cu}_{2} \mathrm{O}$ or $\mathrm{CuO}$ phases in these XRD patterns suggests a high dispersion of $\mathrm{Cu}$ species bound to the MOR support, which is consistent with the fact that no $\mathrm{CuO}_{\mathrm{x}}$ nanoparticles were detectable from the transmission electron microscopy (TEM) images of the Cu-MOR catalysts (Figure S1a of the supporting information). It is worth noting that if the precipitation of $\mathrm{Cu}^{2+}$ ions onto the external surface of the MOR support occurs, the resultant $\mathrm{CuO}_{x}$ particles can be readily observed via the TEM characterization as shown for the Cu-MOR-A sample prepared via the same ion-exchange process but at a slightly higher $\mathrm{pH}$ value $(\mathrm{pH}=6.3$; Figure $\mathrm{S} 1 \mathrm{~b})$. Moreover, even at a Cu loading of $504 \mu \mathrm{mol} \mathrm{g} \mathrm{cat}^{-1}$, the surface area of the Cu-MOR catalyst declined only slightly compared to the parent MOR host (e.g., from 428 to $404 \mathrm{~m}^{2} \mathrm{~g}_{\mathrm{cat}}{ }^{-1}$ for $\mathrm{Cu}-\mathrm{MOR}-\mathrm{C}$; see Figure $1 \mathrm{~b}$ ). These results regarding the high dispersion of copper species were consistent with those reported previously [14,18].
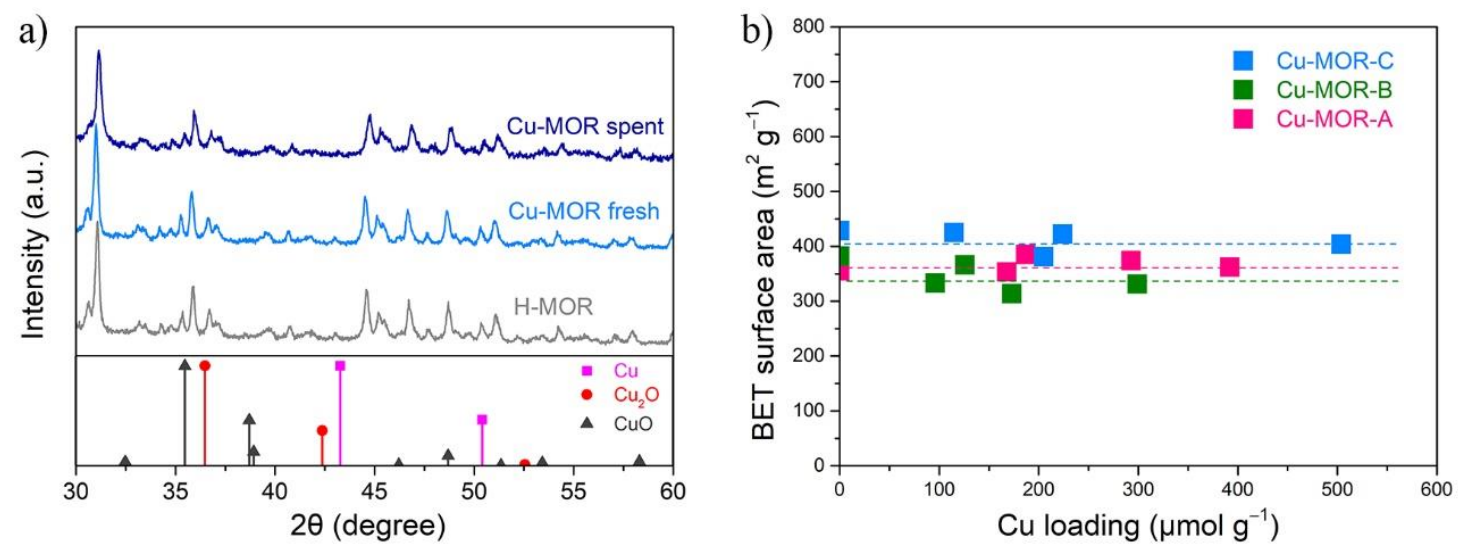

Figure 1. (a) Powder X-ray diffraction patterns for MOR and $\mathrm{Cu}-\mathrm{MOR}$ samples (MOR-A, $\mathrm{Si} / \mathrm{Al}=14$ ) with Cu (PDF-040836), $\mathrm{Cu}_{2} \mathrm{O}$ (PDF-34-1354), and $\mathrm{CuO}$ (PDF-45-0937) as reference; (b) Surface area as a function of Cu loading for the Cu-MOR catalysts.

\subsection{Reactivity of $\mathrm{Cu}-\mathrm{MOR}$ Catalysts for Methane Oxidation}

The activity of these Cu-MOR samples for the selective oxidation of methane was examined via a typical three-step reaction cycle widely applied [17], including (1) activation of the $\mathrm{Cu}-\mathrm{MOR}$ catalysts in flowing $\mathrm{O}_{2}$ at $723 \mathrm{~K},(2)$ introduction of $\mathrm{CH}_{4}$ onto the activated $\mathrm{Cu}-\mathrm{MOR}$ catalysts at $473 \mathrm{~K}$, and (3) extraction of $\mathrm{CH}_{3} \mathrm{OH}$ from the $\mathrm{Cu}-\mathrm{MOR}$ catalysts by steam flushing at $308 \mathrm{~K}$ (Figure 2a). No methanol product was observed in the effluent during the first two steps, and the methanol yield for each run was determined from the cumulative amount of $\mathrm{CH}_{3} \mathrm{OH}$ over the entire period of the third step. It is also noteworthy that the concentration of $\mathrm{CO}_{2}$ in the effluent was below the detection limit, which is consistent with the highly selective conversion of methane to methanol via this chemical looping manner [8-12].

Figure $2 \mathrm{~b}$ shows the methanol yield as a function of the $\mathrm{Cu}$ loading of $\mathrm{Cu}-\mathrm{MOR}-\mathrm{A}$. It was found that the normalized yield remained almost constant $\left(\approx 130 \mathrm{mmol} \mathrm{mol}_{\mathrm{Cu}}{ }^{-1}\right)$ at $\mathrm{Cu}$ loadings of $316 \mu \mathrm{mol} \mathrm{g} \mathrm{cat}^{-1}$ or less, corresponding to a $\mathrm{Cu} / \mathrm{Al}_{\text {acce }}$ ratio of 0.49 for the $\mathrm{Cu}-\mathrm{MOR}-\mathrm{A}$ sample. Then, the methanol yield decreased sharply to $44.8 \mathrm{mmol} \mathrm{mol}_{\mathrm{Cu}}{ }^{-1}$ as the $\mathrm{Cu}$ loading further increased to $668 \mu \mathrm{mol} \mathrm{g} \mathrm{gat}^{-1}$, corresponding to a $\mathrm{Cu} / \mathrm{Al}_{\text {acce }}$ ratio of 1.0, which suggests that the protons of $\mathrm{H}-\mathrm{MOR}-\mathrm{A}$ were completely replaced by $\mathrm{Cu}^{2+}$ cations (in the form of $\mathrm{Cu}(\mathrm{OH})^{+}$cations) during the aqueous ion-exchange preparation of 
$\mathrm{Cu}-\mathrm{MOR}$ catalysts. These results imply that $\mathrm{Cu}^{2+}$ species grafted on the $\mathrm{AlO}_{4}$ tetrahedra units of $\mathrm{H}-\mathrm{MOR}$ at low $\mathrm{Cu}$ loadings are different from those formed at high $\mathrm{Cu}$ loadings for methane oxidation, and the former is much more reactive. Considering that the MOR structures contain both eight-membered-ring (8-MR; $2.6 \times 5.7$ or $3.4 \times 4.8 \AA$ ) and 12 membered-ring (12-MR; $6.5 \times 7.0 \AA$ ) channels (Figure S2) and previous studies have shown that $\mathrm{Cu}^{2+}$ species grafted in the former voids exhibit higher activity in methane activation,,, 17 we suppose that $\mathrm{Cu}^{2+}$ species prefer to exchange the protons residing in the 8-MR channels over those in the 12-MR ones as a consequence of the stronger dispersive stabilization in the smaller confining zeolite voids [35]. Similar effects of $\mathrm{Cu}$ loading on the normalized methanol yield were also observed for the $\mathrm{Cu}-\mathrm{MOR}-\mathrm{B}$ and $\mathrm{Cu}-\mathrm{MOR}-\mathrm{C}$ catalysts (Figure 2c,d), and their threshold loadings were close to 173 and $304 \mu \mathrm{mol} \mathrm{g}_{\mathrm{cat}}{ }^{-1}$, respectively (corresponding to about 0.7 and 1.0 for their respective $\mathrm{Cu} / \mathrm{Al}_{\text {acce }}$ ratios).

a)
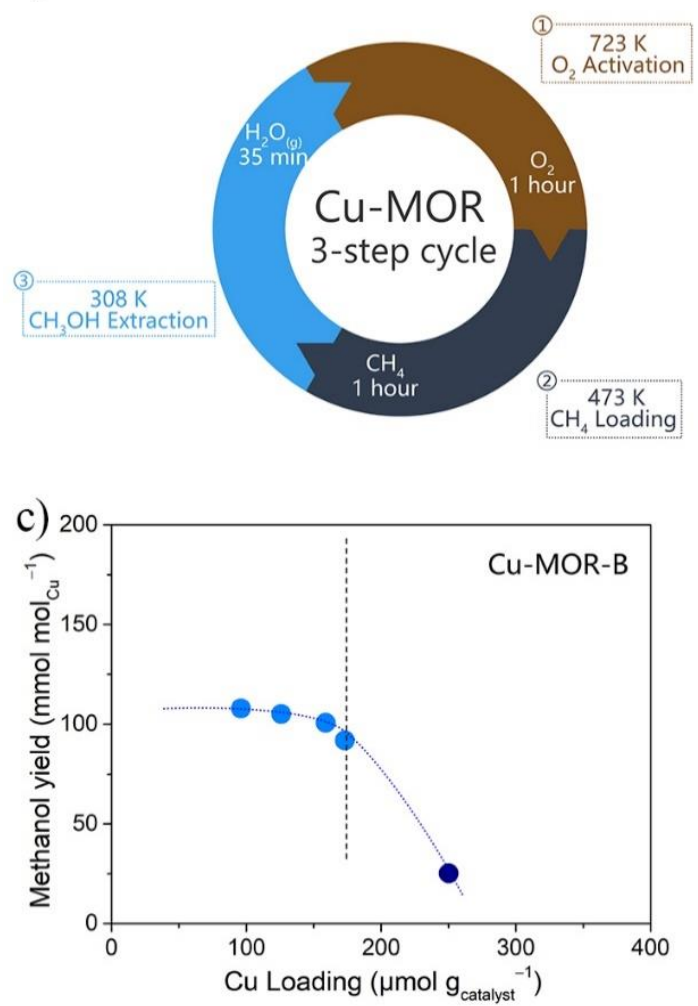

b)

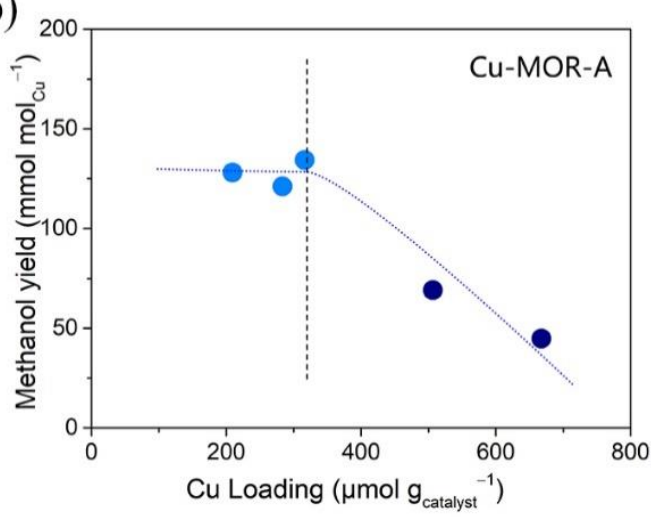

d)

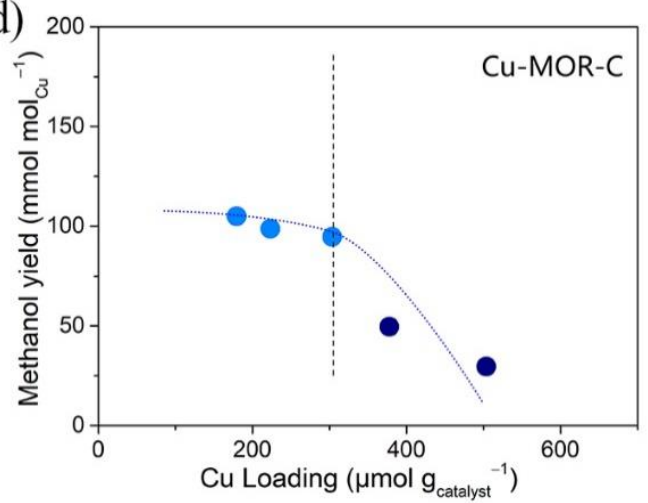

Figure 2. (a) The cyclic process of the methane-to-methanol reaction on $\mathrm{Cu}-\mathrm{MOR}$ catalysts and the methanol yield (normalized by the exchanged $\mathrm{Cu}$ amount) as a function of $\mathrm{Cu}$ loading for (b) $\mathrm{Cu}-\mathrm{MOR}-\mathrm{A}$, (c) Cu-MOR-B, and (d) Cu-MOR-C.

As shown in Figure 2, the methanol yields at the threshold $\mathrm{Cu}$ loading varied from 91.9 to $134.4 \mathrm{mmol} \mathrm{mol}_{\mathrm{Cu}}{ }^{-1}$ for the three examined Cu-MOR samples, and the corresponding yields normalized by the total catalyst mass varied from 20.0 to $42.5 \mu \mathrm{mol} \mathrm{g}_{\text {cat }}{ }^{-1}$. It is notable that these productivity values were apparently lower than the highest one reported in the literature $\left(200 \mu \mathrm{mol} \mathrm{g}_{\mathrm{cat}}{ }^{-1}\right)$ [12]. In addition to the effects of Si / Al ratio and zeolite framework, the lower productivity was likely due to the mild reaction condition applied ( $1 \mathrm{~h}$ of reaction time, 1.0 bar of methane partial pressure, $473 \mathrm{~K}$ ), which was selected to mimic those previously used to study Cu-MOR catalysts. ${ }^{17}$ Recent studies have shown that a long reaction time and a high methane partial pressure are required for a complete reaction of the activated $\mathrm{Cu}$-oxo species with methane [36,37]. Although the reaction conditions in our study were not optimal, the results obtained can still provide valuable information, because all of the methanol yields were evaluated under the same protocol.

The variation of the methanol yields at the threshold Cu loading shown in Figure 2 appears to reflect the distinct $\mathrm{Al}$ distributions among the three $\mathrm{Cu}-\mathrm{MOR}$ samples, as discussed 
above. Specifically, single $\mathrm{Cu}(\mathrm{OH})^{+}$species grafted on the $\mathrm{Al}_{\text {isol }}$ sites can survive from the catalyst activation step at $723 \mathrm{~K}$, while vicinal $\mathrm{Cu}(\mathrm{OH})^{+}$species grafted on the $\mathrm{Al}_{\text {pair }}$ sites tend to form $\mathrm{Cu}_{2} \mathrm{O}_{2}{ }^{2+}, \mathrm{Cu}_{3} \mathrm{O}_{3}{ }^{2+}$, or even larger $\mathrm{Cu}$-oxo clusters (illustrated in Figure $\mathrm{S} 3$ ). Although these $\mathrm{Cu}$-containing moieties have been proposed as active sites for selective methane oxidation to methanol, their relative activities are still under debate [14-21]. As discussed next, in situ UV-Vis spectroscopic characterization of the activated Cu-MOR catalysts confirms that at least two types of $\mathrm{Cu}$-containing moieties exist after the activation process (in flowing $\mathrm{O}_{2}$ at $723 \mathrm{~K}$ ) at low $\mathrm{Cu}$ loadings and they show distinct performances in methane oxidation.

The above discussion suggests that the methanol yield of the Cu-MOR samples is mainly due to the $\mathrm{Cu}$-oxo species grafted in the 8-MR pockets, while those in the larger 12-MR channels are much less active. Assuming that the $\mathrm{Al}_{\text {pair }}$ and $\mathrm{Al}_{\text {isol }}$ sites are evenly distributed in the 8-MR and 12-MR voids, the $\mathrm{Al}_{\text {pair }} / \mathrm{Al}_{\text {isol }}$ ratio is used here as a convenient descriptor to discern the activity contributions of the $\mathrm{Cu}$-containing moieties derived from these two types of sites. Figure 3 plots the methanol yields at the threshold $\mathrm{Cu}$ loading against the $\mathrm{Al}_{\text {pair }} / \mathrm{Al}_{\text {isol }}$ ratios for all the three $\mathrm{Cu}-\mathrm{MOR}$ samples. The obtained positive correlation between the normalized methanol yield and the $\mathrm{Al}_{\text {pair }} / \mathrm{Al}_{\text {isol }}$ ratio clearly indicates that $\mathrm{Cu}_{\mathrm{x}} \mathrm{O}_{\mathrm{y}}$ clusters formed on the $\mathrm{Al}_{\text {pair }}$ sites are preferred for methane activation, which is consistent with our theoretical assessment (shown below).

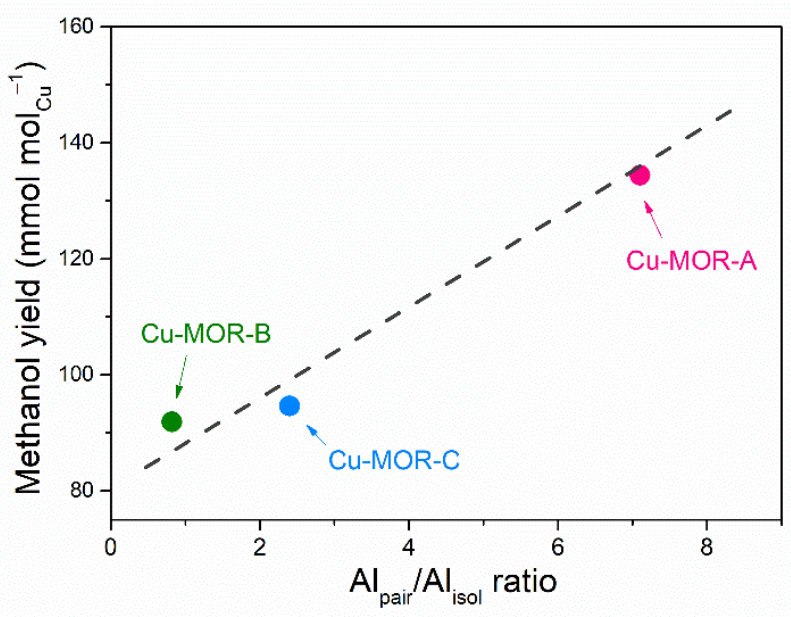

Figure 3. Correlation between $\mathrm{Al}_{\text {pair }} / \mathrm{Al}_{\text {isol }}$ ratios for the three $\mathrm{Cu}-\mathrm{MOR}$ samples and their corresponding methanol yields at the threshold $\mathrm{Cu}$ loading. The dashed line represents a trend line.

\subsection{In Situ UV-Vis Characterization of Methane Oxidation on Cu-MOR}

In situ UV-Vis spectroscopy was employed here to examine the active sites of the $\mathrm{Cu}-\mathrm{MOR}$ catalysts with their corresponding threshold $\mathrm{Cu}$ loadings. As shown in Figure $4 \mathrm{a}$, a broad absorption band centered at $40,900 \mathrm{~cm}^{-1}$ was observed for the Cu-MOR-A sample after the activation treatment in flowing $\mathrm{O}_{2}$ at $723 \mathrm{~K}$, which is ascribable to the charge transfer from $\mathrm{O}^{2-} / \mathrm{OH}^{-}$to $\mathrm{Cu}^{2+}$ ions [17]. After contacting with $\mathrm{CH}_{4}$ at $473 \mathrm{~K}$ for $1 \mathrm{~h}$ (i.e., the $\mathrm{CH}_{4}$ loading step in Figure 2a), the intensity of this absorption band was reduced partially due to the consumption by methane oxidation, which is concomitant with a slight blue-shift of the band peak to $41,200 \mathrm{~cm}^{-1}$. These phenomena suggest that the activated $\mathrm{Cu}$-MOR samples contain at least two types of $\mathrm{Cu}$-containing species, but the very broad feature of these UV-Vis bands hinders a rigorous deconvolution of the overlapping subbands. It is also noteworthy that these UV-Vis bands appear at wavenumbers apparently higher than those reported in the literature $\left(<38,000 \mathrm{~cm}^{-1}\right)[12,38]$, which may be derived from some systematic experimental shift toward higher wavenumbers.

To make a quantitative assessment, we assume that (1) the observed UV-Vis adsorption within the range of $20,000-50,000 \mathrm{~cm}^{-1}$ is derived from two distinct types of $\mathrm{Cu}$-containing species, and (2) both of the corresponding sub-bands have a Gaussian shape with their 
peak positions unchanged for the $\mathrm{Cu}-\mathrm{MOR}$ samples with different $\mathrm{Si} / \mathrm{Al}$ ratios. Based on these hypotheses, we found that the optimized peak positions for the two sub-bands are 38,000 and $42,000 \mathrm{~cm}^{-1}$, respectively, which allow excellent deconvolution for all the three $\mathrm{Cu}-\mathrm{MOR}$ samples. With aid of the time-dependent density functional theory (Figures $\mathrm{S} 4$ and S5), we assigned the high-wavenumber band to the Cu-oxo clusters (e.g., $\mathrm{Cu}_{2} \mathrm{O}_{2}$ or $\mathrm{Cu}_{3} \mathrm{O}_{3}$ ) grafted at the $\mathrm{Al}_{\text {pair }}$ sites and the low-wavenumber one to the $\mathrm{Cu}-\mathrm{OH}$ moiety grafted at the $\mathrm{Al}_{\text {isol }}$ sites. As shown in Figure $4 \mathrm{~b}$, the area ratio of the high-wavenumber band to the low-wavenumber one increased in the order of Cu-MOR-B $(0.55)<\mathrm{Cu}-\mathrm{MOR}-\mathrm{C}$ $(0.77)<\mathrm{Cu}-\mathrm{MOR}-\mathrm{A}(0.86)$, which is in line with the trend for the $\mathrm{Al}_{\text {pair }} / \mathrm{Al}_{\text {isol }}$ ratio of their parent MOR hosts (Table 1). These in situ UV-Vis spectra indicate again that the Cu-oxo clusters derived from the $\mathrm{Al}_{\text {pair }}$ sites of the zeolite framework are the preferred active species for methane activation. However, it needs to be emphasized that the conclusions drawn here are merely derived from the limited three series of $\mathrm{Cu}-\mathrm{MOR}$ catalysts and thus still have uncertainty left.

a)

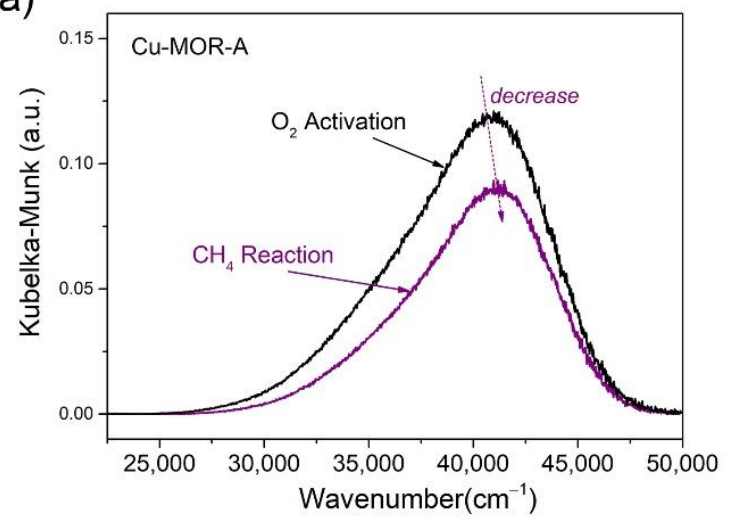

b)

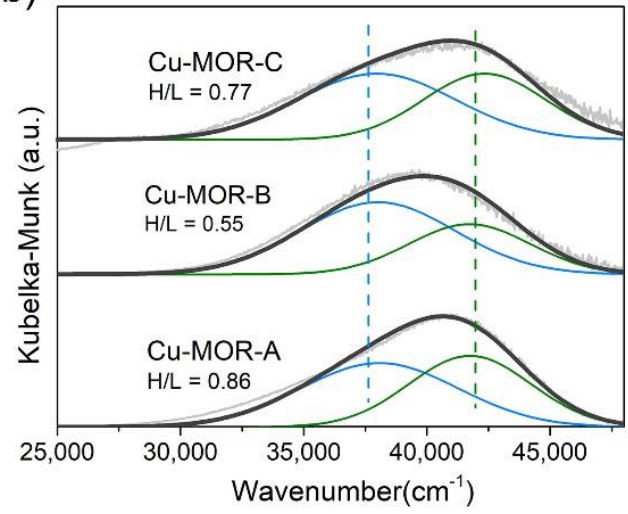

Figure 4. (a) In situ UV-Vis spectra of the activated Cu-MOR-A catalyst before and after the contact with methane at $473 \mathrm{~K}$; (b) Fitting of the UV-Vis signals for the three $\mathrm{Cu}-\mathrm{MOR}$ samples after $\mathrm{O}_{2}$ activation with the area ratio of the highwavenumber band to the low-wavenumber one (H/L) inserted. All the Cu-MOR samples used here are those with their respective threshold $\mathrm{Cu}$ loadings (shown in Figure 3).

\subsection{Theoretical Assessment of Methane Oxidation on $\mathrm{Cu}-\mathrm{MOR}$}

Periodic density functional theory (DFT) analysis was applied to compare the reactivity between the $\mathrm{Cu}$-oxo clusters formed on the $\mathrm{Al}_{\text {pair }}$ sites and the $\mathrm{CuOH}$ group formed on the $\mathrm{Al}_{\text {isol }}$ sites. These $\mathrm{Cu}$-containing species were built and optimized within the side pocket 8-MR of the MOR structure $(3.4 \times 4.8 \AA$; Figure S2), which has been regarded as the preferred host void for methane oxidation [17,39]. Particularly, two types of $\mathrm{Al}_{\text {isol }}$ sites were considered here, as the corresponding $\mathrm{CuOH}$ groups bound to these $\mathrm{Al}_{\text {isol }}$ sites showed apparent difference in orientation (denoted as Cu1-a and Cu1-b; Figure 5a). For the case of $\mathrm{Al}_{\text {pair }}$ sites, two $\mathrm{Si}$ atoms of the 8-MR channel were replaced by $\mathrm{Al}$ atoms equivalently, and three types of $\mathrm{Cu}_{2} \mathrm{O}_{2}$ clusters were constructed based on the number of $(-\mathrm{Si}-\mathrm{O}-)$ units between the two inserted $\mathrm{Al}$ atoms in the resultant ring (denoted as $\mathrm{Cu} 2-n, n=1-3$; Figure $5 \mathrm{a}$ ). It is worth noting that the existence of $\mathrm{Al}-\mathrm{OH}-\mathrm{Si}-\mathrm{O}-\mathrm{Al}-\mathrm{OH}$ motif (i.e., Cu2-1) may have a very low possibility for the H-MOR samples used in our study because of their high $\mathrm{Si} / \mathrm{Al}$ ratios (>14) [40-42], while Cu2-1 was still included here for the completeness of this theoretical assessment. $\mathrm{A} \mathrm{Cu}_{3} \mathrm{O}_{3}$ cluster was also included for the $\mathrm{Al}-\mathrm{OH}-(\mathrm{Si}-\mathrm{O})_{3}-\mathrm{Al}-\mathrm{OH}$ motif (denoted as $\mathrm{Cu} 3$, Figure $5 \mathrm{a}$ ), because several studies reported that such $\mathrm{Cu}_{3} \mathrm{O}_{3}$ clusters were uniquely reactive in methane oxidation [17,21].

Since the cleavage of the first $\mathrm{C}-\mathrm{H}$ bond is generally the rate-determining step in methane activation $[8,20,25]$, the reactivity of these $\mathrm{Cu}$-containing species was evaluated via the dissociation energy of methane $\left(\Delta E_{\text {diss }}\right)$ that is defined as the energy change for 
the dissociation of gaseous methane onto the $\mathrm{Cu}-\mathrm{MOR}$ catalyst to form bound methyl and H-atom moieties:

$$
\Delta E_{\text {diss }}=E_{\mathrm{CH} 3 *+\mathrm{H} *}-E_{\mathrm{Cu}-\mathrm{MOR}}-E_{\mathrm{CH} 4(\mathrm{~g})}
$$

Here, $E_{\mathrm{CH}^{*}+\mathrm{H}^{*}}$ is the energy of the $\mathrm{Cu}$-MOR catalyst with the bound methyl and H-atom species, whereas $E_{\mathrm{Cu}-\mathrm{MOR}}$ and $E_{\mathrm{CH} 4(\mathrm{~g})}$ are the corresponding energies of the unreacted $\mathrm{Cu}-\mathrm{MOR}$ catalyst and the gaseous methane. In particular, a recent theoretical study for methane oxidation [43] has shown that the activation barrier for the $\mathrm{C}-\mathrm{H}$ bond cleavage in methane correlates linearly with the corresponding $\Delta E_{\text {diss }}$ values, indicating that this $\Delta E_{\text {diss }}$ term is an adequate descriptor for the reactivity of different $\mathrm{Cu}$-oxo species on the $\mathrm{C}-\mathrm{H}$ bond cleavage. It is also worth noting that the presence of these bound methyl and $\mathrm{H}$-atom surface intermediates on $\mathrm{Cu}-\mathrm{MOR}$ were confirmed via in situ diffuse reflectance infrared Fourier transform spectroscopy (DRIFTS) measurements (spectra shown in Figure S6).

(a) $\mathrm{Cu} 1-\mathrm{a}$
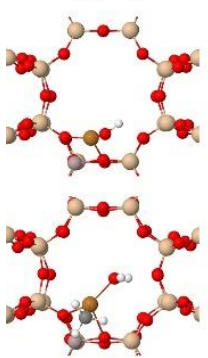

$-0.5 \mathrm{eV}$

(b)

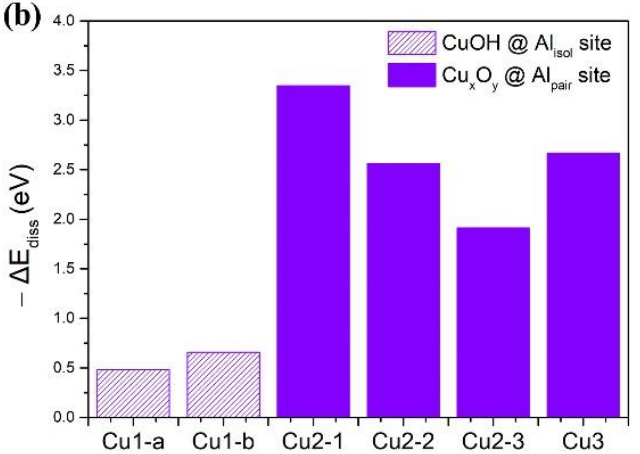

Cu2 - 1
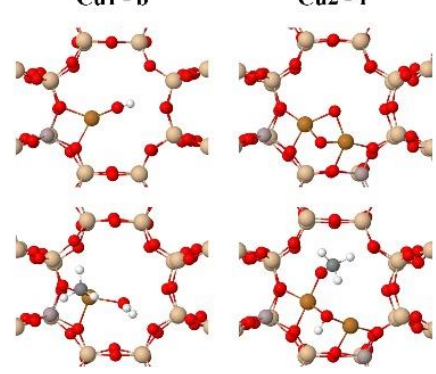

$-0.7 \mathrm{eV}$

$-3.3 \mathrm{eV}$
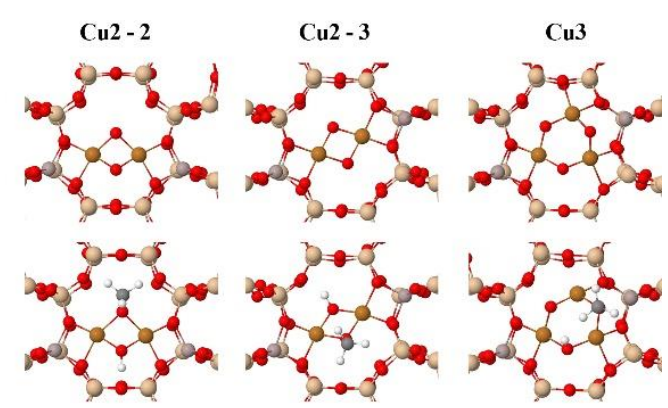

$-2.6 \mathrm{eV}$

$\mathrm{C}$

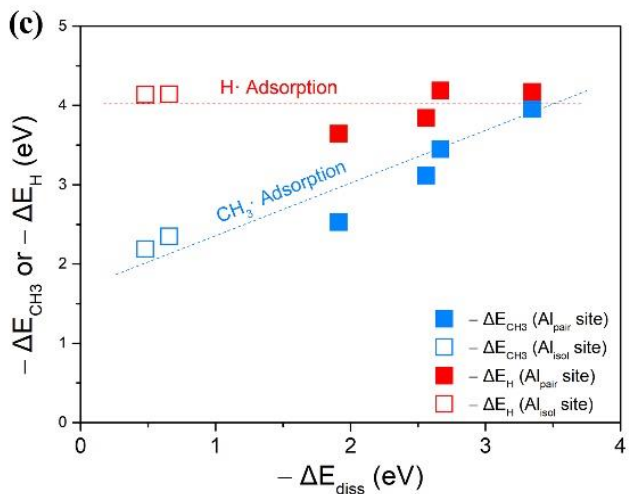

Figure 5. (a) DFT-derived structures of the original Cu-oxo species grafted at the 8-MR of MOR (above) and the corresponding structures after the dissociation of $\mathrm{CH}_{4}$ onto the $\mathrm{Cu}$-oxo species (below); (b) Calculated $\mathrm{CH}_{4}$ dissociation energies $\left(\Delta E_{\text {diss }}\right)$ for the $\mathrm{Cu}$-oxo clusters bound to the $\mathrm{Al}$ pair sites and the $\mathrm{CuOH}$ species bound to the isolated $\mathrm{Al}$ sites; (c) Correlation of the $\mathrm{CH}_{4}$ dissociative adsorption energy $\left(\Delta E_{\text {diss }}\right)$ with the adsorption energies for the $\mathrm{CH}_{3} \cdot\left(\Delta E_{\mathrm{CH} 3^{*}}\right.$, blue squares) and $\mathrm{H}$. $\left(\Delta E_{\mathrm{H}^{*}}\right.$, red squares) groups.

For methane activation on the $\mathrm{CuOH}$ species, our calculations showed that the dissociated methyl and $\mathrm{H}$-atom prefer to locate at the $\mathrm{Cu}$ and $\mathrm{O}$ centers of the $\mathrm{CuOH}$ group, respectively (Figure S7), and the DFT-derived $\Delta E_{\text {diss }}$ values for Cu1-a and Cu1-b were similar with each other ( -0.5 vs. $-0.7 \mathrm{eV}$, Figure $5 \mathrm{~b})$. Compared with the $\mathrm{CuOH}$ species, the bi- $\mu$-O nuclei of the $\mathrm{Cu}_{2} \mathrm{O}_{2}$ clusters can stabilize the dissociated methyl and $\mathrm{H}$-atom moieties more efficiently, leading to much more negative $\Delta E_{\text {diss }}$ values (Cu2-1: $-3.3 \mathrm{eV}$, $\mathrm{Cu} 2-2$ : $-2.6 \mathrm{eV}, \mathrm{Cu} 2-3$ : $-1.9 \mathrm{eV}$; Figure $5 \mathrm{~b}$ ). Similarly, a large value of $-2.7 \mathrm{eV}$ was obtained for $\Delta E_{\text {diss }}$ of the $\mathrm{Cu}_{3} \mathrm{O}_{3}$ clusters that possess tri- $\mu-\mathrm{O}$ nuclei (Figure $5 \mathrm{~b}$ ). These calculated $\Delta E_{\text {diss }}$ numbers indicate that the $\mathrm{Cu}_{2} \mathrm{O}_{2}$ and $\mathrm{Cu}_{3} \mathrm{O}_{3}$ clusters derived from the $\mathrm{Al}_{\text {pair }}$ sites 
are apparently superior to the $\mathrm{CuOH}$ species derived from the $\mathrm{Al}_{\text {isol }}$ sites in methane activation, which is consistent with the experimental findings shown above.

It should be noted that $\Delta E_{\text {diss }}$ for the $\mathrm{Cu}_{2} \mathrm{O}_{2}$ clusters is sensitive to the distance between the two $\mathrm{Al}_{\text {pair }}$ sites in the $8 \mathrm{MR}$. Geometrical analysis of the $\mathrm{Cu}_{2} \mathrm{O}_{2}$ clusters shows that as the number of the $(-\mathrm{Si}-\mathrm{O}-)$ units between the two $\mathrm{Al}$ atoms increased from 1 to 3 , the averaged $\mathrm{Cu}-\mathrm{O}-\mathrm{Cu}$ bond angle increased from $88.8^{\circ}$ to $99.0^{\circ}$, while the $\mathrm{Cu}-\mathrm{O}$ bond length changed only slightly from 1.811 to $1.790 \AA$ (Table S1). Consequently, the tensile force of the $\mathrm{Cu}_{2} \mathrm{O}_{2}$ ring decreased as the two $\mathrm{Al}$ atoms became farther away in the 8-MR, making the $\mathrm{Cu}_{2} \mathrm{O}_{2}$ clusters less active in methane dissociation.

In attempt to capture the key factors that determine the reactivity of $\mathrm{Cu}-\mathrm{MOR}$ catalysts for methane activation, a thermochemical cycle was designed to analyze the methane dissociation on Cu-containing species. As shown in Scheme 2, $\Delta E_{\text {diss }}$ can be decomposed into the energy required for the dissociation of methane to form $\mathrm{CH}_{3}$. and $\mathrm{H}$. radicals in the gas phase $\left(\Delta E_{\text {diss,gas }}\right)$ and the energies released from the bonding of the $\mathrm{CH}_{3} \cdot$ and $\mathrm{H}$. radicals onto the $\mathrm{Cu}$-containing species $\left(\Delta E_{\mathrm{CH}_{3}}\right.$ and $\Delta E_{\mathrm{H}^{*}}$, respectively).

$$
\Delta E_{\text {diss }}=\Delta E_{\text {diss,gas }}+\Delta E_{\mathrm{CH} 3 *}+\Delta E_{\mathrm{H} *}
$$

Specifically, the value of $\Delta E_{\text {diss,gas }}$ merely reflects the intrinsic strength of the $\mathrm{C}-\mathrm{H}$ bond in methane, whereas $\Delta E_{\mathrm{CH}_{3}}$ and $\Delta E_{\mathrm{H}^{*}}$ are those factors relevant to the catalytic reactivity. Figure $5 \mathrm{c}$ depicts the $\Delta E_{\mathrm{CH} 3^{*}}$ and $\Delta E_{\mathrm{H}^{*}}$ values as functions of $\Delta E_{\text {diss }}$ for all the examined $\mathrm{CuOH}$ and $\mathrm{Cu}$-oxo species. It is apparent that $\Delta E_{\mathrm{H}^{*}}$ is nearly insensitive to $\Delta E_{\text {diss, }}$, while a good correlation is obtained between $\Delta E_{\mathrm{CH} 3^{*}}$ and $\Delta E_{\text {diss. }}$. In other words, how to stabilize the methyl moiety on the confined $\mathrm{Cu}$-containing sites is critical in determining the reactivity of $\mathrm{Cu}-\mathrm{MOR}$ catalysts. As shown above, the stabilization of the methyl moiety can be improved by tuning the electronic property of $\mu$-O nuclei or increasing the tensile force of the $\mathrm{Cu}-\mathrm{O}-\mathrm{Cu}$ bond.

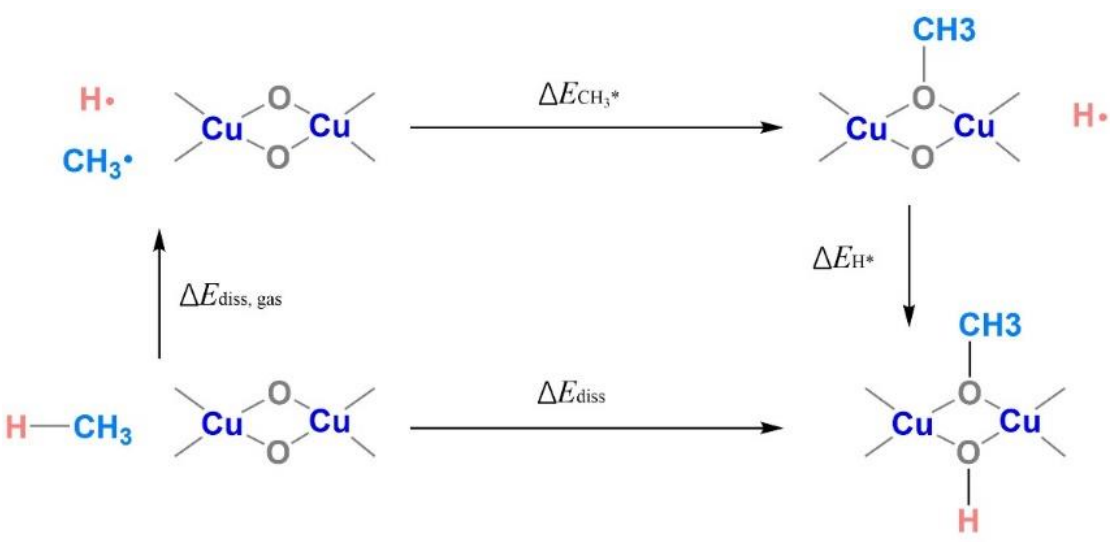

Scheme 2. Thermochemical cycle analysis for the dissociation of methane on $\mathrm{Cu}$-containing species grafted in $\mathrm{MOR}\left(\mathrm{Cu}_{2} \mathrm{O}_{2}\right.$ clusters used here as an example).

\section{Methods}

\subsection{Catalyst Preparation}

$\mathrm{Cu}$-exchanged mordenite ( $\mathrm{Cu}-\mathrm{MOR})$ catalysts with different $\mathrm{Cu}$ loadings were prepared via a conventional aqueous ion-exchange method [17]. Before the ion-exchange process, commercial H-MOR zeolites (two H-MOR samples with $\mathrm{Si} / \mathrm{Al}$ ratios of 14 and 40 purchased from Clariant; one H-MOR sample with a $\mathrm{Si} / \mathrm{Al}$ ratio of 20 purchased from Nankai University Catalyst Co., Ltd.) were pre-treated in a muffle furnace under stagnant ambient air by ramping the temperature from ambient to $773 \mathrm{~K}$ at $1 \mathrm{~K} \mathrm{~s}^{-1}$ and holding for $5 \mathrm{~h}$. The $\mathrm{Cu}^{2+}$ exchange was carried out at ambient temperature by mixing $2.0 \mathrm{~g}$ zeolite with $120 \mathrm{~mL}$ of aqueous $\mathrm{Cu}\left(\mathrm{CH}_{3} \mathrm{COO}\right)_{2}$ (AR, Xilong Scientific Co., Ltd., Guangdong, China) solution. The $\mathrm{Cu}\left(\mathrm{CH}_{3} \mathrm{COO}\right)_{2}$ concentration of the solution was varied between 0.0025 and 
$0.025 \mathrm{~mol} \mathrm{~L}^{-1}$ to obtain copper loadings of $0.1-0.7 \mathrm{mmol} \mathrm{g}^{-1}$. During this ion-exchange process, the $\mathrm{pH}$ value of the aqueous solution was controlled to around 5.4 via adding a diluted $\mathrm{NH}_{4} \mathrm{OH}$ solution (Sinopharm Group Co., Ltd., Shanghai, China). After the ion exchange for $24 \mathrm{~h}$, the resultant solid was separated via centrifugation and washed by deionized water four times. Then, these samples were dried in static ambient air at $373 \mathrm{~K}$ overnight. The calcination and activation of these $\mathrm{Cu}$-exchanged catalysts were conducted in following $\mathrm{O}_{2}$ at $723 \mathrm{~K}$ in situ during the stepwise oxidation of methane to methanol as described in Section 3.3.

\subsection{Catalyst Characterization}

The crystal structures of catalysts were determined from the powder X-ray diffraction (XRD) patterns collected in Rigaku D/MAX-rC $\left(\mathrm{Cu}-K_{\alpha}\right.$ radiation, $\lambda=1.5418 \AA$, $35 \mathrm{kV}$, $15 \mathrm{~mA}$, Tokyo, Japan). The data were recorded by increasing the $2 \theta$ value from $5^{\circ}$ to $60^{\circ}$ $\left(10^{\circ} \mathrm{min}^{-1}\right)$. The morphology of $\mathrm{Cu}-\mathrm{MOR}$ was examined on the Tecnai G2 F20 transmission electron microscope (TEM; FEI, USA) operating at $200 \mathrm{kV}$. The concentrations of $\mathrm{Cu}$, Al, and Si elements in the $\mathrm{Cu}-\mathrm{MOR}$ catalysts were quantified by $\mathrm{X}$-ray Fluorescence Spectrometer (XRF) using BRUKER S8 TIGER (60 kV, $40 \mathrm{~mA}, 1084 \mathrm{mbar}^{2} .0 \mathrm{~mL} \mathrm{~min}^{-1}$, MA, USA), while the surface area of the solid samples was measured on Micromeritics Tristar 2020 (GA, USA) at $78 \mathrm{~K}$ after a thermal pretreatment ( $513 \mathrm{~K}, 4 \mathrm{~h}$, vacuum). The aluminum distribution of the examined MOR zeolites was probed by $\mathrm{Na}^{+}$and $\mathrm{Co}^{2+}$ ion-exchange methods, since these two ions can selectively exchange the protons derived from the different $\mathrm{Al}$ sites in the zeolite framework $[17,31]$. Specifically, the $\mathrm{Na}^{+}$-exchange of the H-MOR zeolites was conducted in a $0.05 \mathrm{~mol} \mathrm{~L}^{-1} \mathrm{NaNO}_{3}$ solution for $24 \mathrm{~h}$ at $333 \mathrm{~K}$, which was followed by drying at $373 \mathrm{~K}$ for $24 \mathrm{~h}$. The $\mathrm{Co}^{2+}$-exchange of the resultant $\mathrm{Na}-\mathrm{MOR}$ samples was conducted in a $0.05 \mathrm{~mol} \mathrm{~L}{ }^{-1} \mathrm{Co}\left(\mathrm{NO}_{3}\right)_{2}$ solution at ambient temperature 3 times, and each time, it lasted for $12 \mathrm{~h}$. The concentrations of $\mathrm{Na}$ and Co elements in the exchanged samples were determined by the inductively coupled plasma optical emission spectrometry (ICP, Thermo Fisher Scientific, Waltham, MA, USA, ICAP7400).

\subsection{Testing of Activity for Methane Oxidation to Methanol}

The activity of $\mathrm{Cu}-\mathrm{MOR}$ catalysts was evaluated in a U-shaped quartz reactor with an inner diameter of $8 \mathrm{~mm}$. The reaction process consisted of three sequential steps, including activation by $\mathrm{O}_{2}$, reaction with $\mathrm{CH}_{4}$, and extraction with $\mathrm{H}_{2} \mathrm{O}$ stream. In a typical experiment, $0.2 \mathrm{~g} \mathrm{Cu}-\mathrm{MOR}(250-380 \mu \mathrm{m})$ was treated in flowing $\mathrm{O}_{2}\left(16 \mathrm{~mL} \mathrm{~min}^{-1}\right)$ at $723 \mathrm{~K}$ for $1 \mathrm{~h}$ and then cooled down to $473 \mathrm{~K}$. After purging in $\mathrm{He}$, the sample was treated in $90 \%$ $\mathrm{CH}_{4} / \mathrm{He}\left(19 \mathrm{~mL} \mathrm{~min}^{-1}\right)$ at $473 \mathrm{~K}$ for $1 \mathrm{~h}$ and then cooled to $308 \mathrm{~K}$ and purged in $\mathrm{He}$. In the last step, a mixture of $\mathrm{H}_{2} \mathrm{O}$ stream $\left(14 \mathrm{~mL} \mathrm{~min}^{-1}\right)$ and $\mathrm{He}\left(10 \mathrm{~mL} \mathrm{~min}^{-1}\right)$ passed through the catalyst bed for $35 \mathrm{~min}$. These reaction parameters were adopted from those previously used to study $\mathrm{Cu}-\mathrm{MOR}$ catalysts ${ }^{17}$ and were not further optimized. The reaction products were detected and quantified by an online mass spectroscopy (OmniStar ${ }^{\mathrm{TM}} /$ ThermoStar $^{\mathrm{TM}}$ GSD320 Gas Analysis System, Headquarters, Germany) through monitoring the signals at $m / z$ ratios of 31,44 , and 46 , which were ascribed to the formed $\mathrm{CH}_{3} \mathrm{OH}, \mathrm{CO}_{2}$, and $\left(\mathrm{CH}_{3} \mathrm{O}\right)_{2} \mathrm{O}$ species, respectively.

\subsection{Ultraviolet-Visible Spectroscopy Measurements}

Ultraviolet-visible (UV-Vis) spectra were acquired on Agilent Cary 100 (Santa Clara, CA, USA) in the range from 20,000 to $50,000 \mathrm{~cm}^{-1}$ at $15,000 \mathrm{~cm}^{-1} \mathrm{~min}^{-1}$. The gaseous environment during the UV-Vis measurement was identical to the process for the activity testing. The signal of each fresh catalyst was collected as the respective baseline. The intensity of the diffuse reflectance UV-Vis spectra was presented in the form of the KubelkaMunk function as given by

$$
\mathrm{F}(R)=(1-R)^{2} \div(2 \times R)
$$


where $R$ is the ratio of the reflectance of the sample in reaction to the reflectance of the fresh sample.

\subsection{Periodic Density Functional Theory Treatments}

The periodic density functional theory (DFT) calculations of adsorption energy within the MOR structure $(\mathrm{a}=18.09 \AA, \mathrm{b}=20.52 \AA$, $\mathrm{c}=7.52 \AA$; modeled with a $1 \times 1 \times 2$ unit cell) were carried out using Vienna ab initio simulation package (VASP, version 5.4.1) [44-47]. The electron exchange-correlation was treated by the generalized gradient approximation (GGA) based on the Perdew-Burke-Ernzerhof (PBE) functional [48], and van der Waals correction was included using the Grimme's D3BJ method [49]. The plane wave basis set was truncated with a cutoff energy of $400 \mathrm{eV}$. The Brillouin zone was sampled using the gamma point, whereas the Gaussian smearing was set at $0.05 \mathrm{eV}$. All atoms were allowed to relax during geometry optimizations until the maximum force on each atom was less than $0.05 \mathrm{eV}^{\mathrm{A}}-1$.

\section{Conclusions}

The quantification of isolate $\mathrm{Al}$ sites and $\mathrm{Al}$ pair sites within the MOR zeolite host by conventional $\mathrm{Na}^{+} / \mathrm{Co}^{2+}$ aqueous ion-exchange methods provides an effective approach to discern the reactivity difference between the $\mathrm{Cu}$-containing species derived from the accessiable framework Al sites for methane oxidation to methanol. Particularly, the most reactive $\mathrm{Cu}$-containing species for the $\mathrm{Cu}-\mathrm{MOR}$ catalysts are those formed at low $\mathrm{Cu}$ loadings, which plausibly reside in the 8-MR channels instead of the 12-MR ones. A good correlation between the methanol yield (normalized by the $\mathrm{Cu}$ amount) at low $\mathrm{Cu}$ loadings and the ratio of the $\mathrm{Al}$ pair sites to the isolate $\mathrm{Al}$ sites suggests that the observed activity of $\mathrm{Cu}-\mathrm{MOR}$ in methane oxidation is mainly ascribed to the $\mathrm{Cu}$-oxo clusters grafted at the Al pair sites. In situ UV-Vis spectroscopic measurements and DFT calculations further support that these $\mathrm{Cu}$-oxo clusters are more reactive than the $\mathrm{CuOH}$ species bound to the isolated $\mathrm{Al}$ sites. By applying a theoretical analysis on the energetics of the first $\mathrm{C}-\mathrm{H}$ bond cleavage in methane, it is unveiled that the stabilization of the formed methyl moiety onto the $\mathrm{Cu}$-containing species determines the reactivity of methane oxidation, and the bridged-O centers within the $\mathrm{Cu}$-oxo clusters are favored to hold the methyl moieties, which accounts for the higher reactivity of these $\mathrm{Cu}$-oxo clusters than the $\mathrm{CuOH}$ species.

Supplementary Materials: The following are available online at https:/ / www.mdpi.com/article/10 .3390 / catal11060751/s1, Figure S1: TEM images for the Cu-MOR-A catalyst $\left(424 \mu \mathrm{molCu}_{\text {gcatalyst }}{ }^{-1}\right)$ prepared at constant $\mathrm{pH}$ values of (a) 5.4 and (b) 6.3; Figure S2: Illustration of the 12-MR and 8-MR motifs in MOR; Figure S3: Formation of $\mathrm{Cu}_{2} \mathrm{O}_{2}$ clusters from two vicinal $\mathrm{CuOH}$ species bound to Al pair sites in MOR; Figure S4: Predicted UV-Vis spectra of the MOR-supported Cu-oxo species before (solid) and after (dotted) reaction with methane; Figure S5: Predicted UV-Vis spectra of the MOR zeolite structure; Figure S6; in situ Diffuse reflectance infrared Fourier transform spectra for an activated $\mathrm{Cu}-\mathrm{MOR}-\mathrm{A}$ sample after the methane oxidation process at $473 \mathrm{~K}$ for $1 \mathrm{~h}$; Figure S7: DFTderived structures for $\mathrm{Cu1}-\mathrm{b}$ bound with dissociated methyl and $\mathrm{H}$ moieties and the corresponding dissociation energy of methane; Table S1: DFT-derived geometric parameters and charge distribution for the $\mathrm{Cu}$-oxo species before and after methane dissociation onto them.

Author Contributions: Y.W. and S.W. (Shuai Wang) conceived the idea for the project. P.H., Z.Z. and Z.C. conducted the catalyst synthesis and performed the catalytic tests. P.H. conducted the theoretical calculations. P.H. drafted the manuscript under the guidance of S.W. (Shuai Wang), J.L., S.W. (Shaolong Wan) and Y.W. All authors discussed and commented on the manuscript.

Funding: This work was supported by the National Natural Science Foundation of China (No. 91945301, 21922201, 21872113, and 91545114) and the Fundamental Research Funds for the Central Universities (No. 20720190036).

Conflicts of Interest: There are no conflict to declare. 


\section{References}

1. Meng, X.; Cui, X.; Rajan, N.P.; Yu, L.; Deng, D.; Bao, X. Direct Methane Conversion under Mild Condition by Thermo-, Electro-, or Photocatalysis. Chem 2019, 5, 2296-2325. [CrossRef]

2. Saha, D.; Grappe, H.A.; Chakraborty, A.; Orkoulas, G. Postextraction Separation, On-Board Storage, and Catalytic Conversion of Methane in Natural Gas: A Review. Chem. Rev. 2016, 116, 11436-11499. [CrossRef]

3. Sun, L.; Wang, Y.; Guan, N.; Li, L. Methane Activation and Utilization: Current Status and Future Challenges. Energy Technol. 2019, 8, 1900826. [CrossRef]

4. Bao, J.; Yang, G.; Yoneyama, Y.; Tsubaki, N. Significant Advances in C1 Catalysis: Highly Efficient Catalysts and Catalytic Reactions. ACS Catal. 2019, 9, 3026-3053. [CrossRef]

5. Lian, M.; Wang, Y.; Zhao, M.; Li, Q.; Weng, W.; Xia, W.; Wan, H. Stability of $\mathrm{Ni} / \mathrm{SiO}_{2}$ in Partial Oxidation of Methane: Effects of W Modification. Acta Phys. Chim. Sin. 2019, 35, 607-615. [CrossRef]

6. Jin, Z.; Wang, L.; Zuidema, E.; Mondal, K.; Zhang, M.; Zhang, J.; Wang, C.; Meng, X.; Yang, H.; Mesters, C.; et al. Hydrophobic Zeolite Modification for in situ Peroxide Formation in Methane Oxidation to Methanol. Science 2020, 367, 193-197. [CrossRef]

7. Sun, L.; Wang, Y.; Wang, C.; Xie, Z.; Guan, N.; Li, L. Water-Involved Methane-Selective Catalytic Oxidation by Dioxygen over Copper Zeolites. Chem 2021, 7, 1557-1568. [CrossRef]

8. Ravi, M.; Ranocchiari, M.; van Bokhoven, J.A. The Direct Catalytic Oxidation of Methane to Methanol-A Critical Assessment. Angew. Chem. Int. Ed. 2017, 56, 16464-16483. [CrossRef]

9. Tomkins, P.; Ranocchiari, M.; van Bokhoven, J.A. Direct Conversion of Methane to Methanol under Mild Conditions over Cu-Zeolites and beyond. Acc. Chem. Res. 2017, 50, 418-425. [CrossRef] [PubMed]

10. Snyder, B.E.R.; Bols, M.L.; Schoonheydt, R.A.; Sels, B.F.; Solomon, E.I. Iron and Copper Active Sites in Zeolites and Their Correlation to Metalloenzymes. Chem. Rev. 2018, 118, 2718-2768. [CrossRef]

11. Mahyuddin, M.H.; Shiota, Y.; Yoshizawa, K. Methane selective oxidation to methanol by metal-exchanged zeolites: A review of active sites and their reactivity. Catal. Sci. Technol. 2019, 9, 1744-1768. [CrossRef]

12. Newton, M.A.; Knorpp, A.J.; Sushkevich, V.L.; Palagin, D.; van Bokhoven, J.A. Active sites and mechanisms in the direct conversion of methane to methanol using $\mathrm{Cu}$ in zeolitic hosts: A critical examination. Chem. Soc. Rev. 2020, 49, 1449-1486. [CrossRef] [PubMed]

13. Que, L., Jr.; Tolman, W.B. Biologically inspired oxidation catalysis. Nature 2008, 455, 333-340. [CrossRef] [PubMed]

14. Bozbag, S.E.; Alayon, E.M.C.; Pechacek, J.; Nachtegaal, M.; Ranocchiari, M.; van Bokhoven, J.A. Methane to methanol over copper mordenite: Yield improvement through multiple cycles and different synthesis techniques. Catal. Sci. Technol. 2016, 6, 5011-5022. [CrossRef]

15. Groothaert, M.H.; Smeets, P.J.; Sels, B.F.; Jacobs, P.A.; Schoonheydt, R.A. Selective oxidation of methane by the bis(muoxo)dicopper core stabilized on ZSM-5 and mordenite zeolites. J. Am. Chem. Soc. 2005, 127, 1394-1395. [CrossRef] [PubMed]

16. Grundner, S.; Luo, W.; Sanchez-Sanchez, M.; Lercher, J.A. Synthesis of single-site copper catalysts for methane partial oxidation. Chem. Commun. 2016, 52, 2553-2556. [CrossRef] [PubMed]

17. Grundner, S.; Markovits, M.A.; Li, G.; Tromp, M.; Pidko, E.A.; Hensen, E.J.; Jentys, A.; Sanchez-Sanchez, M.; Lercher, J.A. Single-site trinuclear copper oxygen clusters in mordenite for selective conversion of methane to methanol. Nat. Commun. 2015, 6, 7546. [CrossRef]

18. Le, H.V.; Parishan, S.; Sagaltchik, A.; Gobel, C.; Schlesiger, C.; Malzer, W.; Trunschke, A.; Schomacker, R.; Thomas, A. Solid-State Ion-Exchanged Cu/Mordenite Catalysts for the Direct Conversion of Methane to Methanol. ACS Catal. 2017, 7, 1403-1412. [CrossRef]

19. Narsimhan, K.; Iyoki, K.; Dinh, K.; Roman-Leshkov, Y. Catalytic Oxidation of Methane into Methanol over Copper-Exchanged Zeolites with Oxygen at Low Temperature. ACS Cent. Sci. 2016, 2, 424-429. [CrossRef]

20. Sushkevich, V.L.; Palagin, D.; Ranocchiari, M.; van Bokhoven, J.A. Selective anaerobic oxidation of methane enables direct synthesis of methanol. Science 2017, 356, 523-527. [CrossRef]

21. Sushkevich, V.L.; Palagin, D.; van Bokhoven, J.A. The Effect of the Active-Site Structure on the Activity of Copper Mordenite in the Aerobic and Anaerobic Conversion of Methane into Methanol. Angew. Chem. Int. Ed. 2018, 57, 8906-8910. [CrossRef]

22. Wang, G.R.; Chen, W.; Huang, L.; Liu, Z.Q.; Sun, X.Y.; Zheng, A.M. Reactivity descriptors of diverse copper-oxo species on ZSM-5 zeolite towards methane activation. Catal. Today 2019, 338, 108-116. [CrossRef]

23. Woertink, J.S.; Smeets, P.J.; Groothaert, M.H.; Vance, M.A.; Sels, B.F.; Schoonheydt, R.A.; Solomon, E.I. A [Cu 2$]^{2+}$ core in $^{2}$ Cu-ZSM-5, the active site in the oxidation of methane to methanol. Proc. Natl. Acad. Sci.USA 2009, 106, 18908-18913. [CrossRef]

24. Pappas, D.K.; Borfecchia, E.; Dyballa, M.; Pankin, I.A.; Lomachenko, K.A.; Martini, A.; Signorile, M.; Teketel, S.; Arstad, B.; Berlier, G.; et al. Methane to Methanol: Structure-Activity Relationships for Cu-CHA. J. Am. Chem. Soc. 2017, 139, 14961-14975. [CrossRef]

25. Kulkarni, A.R.; Zhao, Z.-J.; Siahrostami, S.; Nørskov, J.K.; Studt, F. Monocopper Active Site for Partial Methane Oxidation in Cu-Exchanged 8MR Zeolites. ACS Catal. 2016, 6, 6531-6536. [CrossRef]

26. Knorpp, A.; Pinar, A.B.; Baerlocher, C.; McCusker, L.B.; Casati, N.; Newton, M.A.; Checchia, S.; Meyet, J.; Palagin, D.; van Bokhoven, J.A. Paired copper monomers in zeolite omega: The active site for methane-to-methanol conversion. Angew. Chem. Int. Ed. 2021, 60, 5854-5858. [CrossRef] 
27. Mahyuddin, M.H.; Tanaka, T.; Shiota, Y.; Staykov, A.; Yoshizawa, K. Methane Partial Oxidation over $\left[\mathrm{Cu} \mathrm{u}_{2}(\mu-\mathrm{O})\right]^{2+}$ and $\left[\mathrm{Cu}_{3}(\mu-\right.$ $\left.\mathrm{O})_{3}\right]^{2+}$ Active Species in Large-Pore Zeolites. ACS Catal. 2018, 8, 1500-1509. [CrossRef]

28. Palagin, D.; Knorpp, A.J.; Pinar, A.B.; Ranocchiari, M.; van Bokhoven, J.A. Assessing the relative stability of copper oxide clusters as active sites of a CuMOR zeolite for methane to methanol conversion: Size matters? Nanoscale 2017, 9, 1144-1153. [CrossRef] [PubMed]

29. Dědeček, J.; Kaucký, D.; Wichterlová, B. $\mathrm{Co}^{2+}$ ion siting in pentasil-containing zeolites, part 3. Microporous Mesoporous Mater. 2000, 35-36, 483-494. [CrossRef]

30. Dědeček, J.; Kaucký, D.; Wichterlová, B. Al distribution in ZSM-5 zeolites: An experimental study. Chem. Commun. 2001, 970-971. [CrossRef]

31. Dědeček, J.; Kaucký, D.; Wichterlová, B.; Gonsiorová, O. $\mathrm{Co}^{2+}$ ions as probes of Al distribution in the framework of zeolites. ZSM-5 study. Phys. Chem. Chem. Phys. 2002, 4, 5406-5413. [CrossRef]

32. Karcz, R.; Dedecek, J.; Supronowicz, B.; Thomas, H.M.; Klein, P.; Tabor, E.; Sazama, P.; Pashkova, V.; Sklenak, S. TNU-9 Zeolite: Aluminum Distribution and Extra-Framework Sites of Divalent Cations. Chem. Eur. J. 2017, 23, 8857-8870. [CrossRef] [PubMed]

33. Mlekodaj, K.; Dedecek, J.; Pashkova, V.; Tabor, E.; Klein, P.; Urbanova, M.; Karcz, R.; Sazama, P.; Whittleton, S.R.; Thomas, H.M.; et al. Al Organization in the SSZ-13 Zeolite. Al Distribution and Extraframework Sites of Divalent Cations. J. Phys. Chem. C 2018, 123, 7968-7987. [CrossRef]

34. Indovina, V.; Campa, M.C.; Pietrogiacomi, D. Isolated $\mathrm{Co}^{2+}$ and $[\mathrm{Co}-\mathrm{O}-\mathrm{Co}]^{2+}$ Species in Na-MOR Exchanged with Cobalt to Various Extents: An FTIR Characterization by CO Adsorption of Oxidized and Prereduced Samples. J. Phys. Chem. C 2008, 112, 5093-5101. [CrossRef]

35. Gounder, R.; Iglesia, E. The catalytic diversity of zeolites: Confinement and solvation effects within voids of molecular dimensions. Chem. Commun. 2013, 49, 3491-3509. [CrossRef]

36. Tomkins, P.; Mansouri, A.; Bozbag, S.E.; Krumeich, F.; Park, M.B.; Alayon, E.M.C.; Ranocchiari, M.; van Bokhoven, J.A. Isothermal cyclic conversion of methane into methanol over copper-exchanged zeolite at low temperature. Angew. Chem. Int. Ed. 2016, 55, 5467-5471. [CrossRef]

37. Brezicki, G.; Kammert, J.D.; Gunnoe, T.B.; Paolucci, C.; Davis, R.J. Insights into the speciation of Cu in the Cu-H-mordenite catalyst for the oxidation of methane to methanol. ACS Catal. 2019, 9, 5308-5319. [CrossRef]

38. Ikuno, T.; Grundner, S.; Jentys, A.; Li, G.; Pidko, E.; Fulton, J.; Sanchez-Sanchez, M.; Lercher, J.A. Formation of Active Cu-oxo Clusters for Methane Oxidation in Cu-Exchanged Mordenite. J. Phys. Chem. C 2019, 123, 8759-8769. [CrossRef]

39. Vanelderen, P.; Snyder, B.E.; Tsai, M.L.; Hadt, R.G.; Vancauwenbergh, J.; Coussens, O.; Schoonheydt, R.A.; Sels, B.F.; Solomon, E.I. Spectroscopic definition of the copper active sites in mordenite: Selective methane oxidation. J. Am. Chem. Soc. 2015, 137, 6383-6392. [CrossRef]

40. Dědeček, J.; Sklenak, S.; Li, C.; Wichterlová, B.; Gábová, V.; Brus, J.; Sierka, M.; Sauer, J. Effect of Al-Si-Al and Al-Si-Si-Al Pairs in the ZSM-5 Zeolite Framework on the ${ }^{27}$ Al NMR Spectra. A Combined High-Resolution ${ }^{27}$ Al NMR and DFT/MM Study. J. Phys. Chem. C 2009, 113, 1447-1458. [CrossRef]

41. Takaishi, T.; Kato, M.; Itabashi, K. Determination of the ordered distribution of aluminum atoms in a zeolitic framework. Part II. Zeolites 1995, 15, 21-32. [CrossRef]

42. Takaishi, T.; Kato, M.; Itabashi, K. Stability of the Al-O-Si-O-Al Linkage in a Zeolitic Framework. J. Phys. Chem. 1994, 98, 5742-5743. [CrossRef]

43. Arvidsson, A.A.; Zhdanov, V.P.; Carlsson, P.-A.; Grönbeck, H.; Hellman, A. Metal dimer sites in ZSM-5 zeolite for methane-tomethanol conversion from first-principles kinetic modelling: Is the $[\mathrm{Cu}-\mathrm{O}-\mathrm{Cu}]^{2+}$ motif relevant for $\mathrm{Ni}, \mathrm{Co}, \mathrm{Fe}, \mathrm{Ag}$, and $\mathrm{Au}$ ? Catal. Sci. Technol. 2017, 7, 1470-1477. [CrossRef]

44. Kresse, G.; Hafner, J. Ab initio molecular dynamics for open-shell transition metals. Phys. Rev. B Condens. Matter 1993, 48, 13115-13118. [CrossRef]

45. Kresse, G.; Hafner, J. Ab initio molecular-dynamics simulation of the liquid-metal-amorphous-semiconductor transition in germanium. Phys. Rev. B Condens. Matter 1994, 49, 14251-14269. [CrossRef]

46. Kresse, G.; Furthmuller, J. Efficiency of ab-initio total energy calculations for metals and semiconductors using a plane-wave basis set. Comput. Mater. Sci. 1996, 6, 15-50. [CrossRef]

47. Kresse, G.; Furthmuller, J. Efficient iterative schemes for ab initio total-energy calculations using a plane-wave basis set. Phys. Rev. B Condens. Matter 1996, 54, 11169-11186. [CrossRef] [PubMed]

48. Perdew, J.P.; Burke, K.; Ernzerhof, M. Generalized Gradient Approximation Made Simple. Phys. Rev. Lett. 1996, 77, 3865-3868. [CrossRef]

49. Grimme, S. Semiempirical GGA-type density functional constructed with a long-range dispersion correction. J. Comput. Chem. 2006, 27, 1787-1799. [CrossRef] [PubMed] 